Edu Consilium: Jurnal BK Pendidikan Islam

Vol 2, No. 1, Februari 2021, hlm. 87 - 99

ISSN 2503-3417 (online)

ISSN 2548-4311 (cetak)

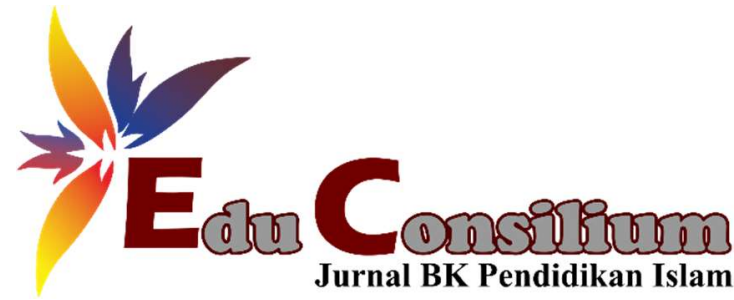

\title{
LAYANAN BIMBINGAN KELOMPOK TEKNIK SOSIODRAMA UNTUK MENINGKATKAN KETERAMPILAN KOMUNIKASI SISWA
}

\author{
Maisunah \\ Program Studi Bimbingan dan Konseling Pendidikan Islam, Fakultas Tarbiyah, IAIN Madura \\ email: maisunah620@gmail.com
}

\begin{tabular}{l}
\hline Keywords: \\
Group \\
Guidance; \\
Oral \\
Communicatio \\
n; \\
Sociodrama.
\end{tabular}

Abstract

Many students experienced oral communication skill problem. One of them is class VII students at MTs. An-Najah I who had low communication skill. Therefore, guidance and counseling services are needed to deliver by the school counselor. Group guidance service with sociodarama tecnique was considered to help increasing students' communication skill. Based on that, there are two research focuses: First, how is the implementation of group guidance services using the sociodrama technique to improve students' oral communication skill; second, what are the supporting and inhibiting factors in the implementation of group guidance service using the sociodrama technique in improving students' communication skill.

This research was an Action Guidance and Counseling Research in which conducted at MTs. An-Najah I Karduluk Sumenep with 20 students of grade VII as as the subjects. This research was carried out in 2 cycles and each cycle consist of 3 meetings. The data collection techniques were observation, interview, and documentation. Anda descriptive statistics used as the data analysis technique to find the average and qualitative descriptive analysis.

The results of this study indicate that sociodrama technique can improve the oral communication skill of grade VII students of MTs An-Najah I. Students' oral communication skill score before treatment was 46.6. Then in the first cycle they obtained an average score of 76.09, an increase in the score of 29.49. In Cycle II, an average score of 88.40 was obtained, there was an increase in the score of 12.31 from cycle I. Hence, the total increase was 41.8 from pre-action to cycle II.

Moreover, supporting factors of the implementation of group guidance services using the sociodrama technique in improving students' oral communication skill were a conducive classroom atmospherethe enthusiastic and excitement of the students. While the inhibiting factors were the lack of supporting and the restricted space for playing the sociodarama.

\begin{tabular}{cl}
\hline & \multicolumn{1}{c}{ Abstrak: } \\
\hline Kata Kunci: & Banyak siswa yang memiliki masalah dengan ketermpilan komunikasi lisannya, hal ini \\
Bimbingan & dapat di temukan di lingkungan sekolah mereka pada siswa kelas VII di MTs. An-Najah \\
Kelompok; & I. Berdasarkan hal tersebut, penelitian ini ingin mengetahui: Pertama bagaimana \\
Komunikasi Lisan; & penerapan layanan bimbingan kelompok dengan metode sosiodrama dalam \\
Sosiodrama. & meningkatkan komunikasi lisan pada siswa kelas VII MTs. An-najah I Karduluk, kedua \\
& apa saja faktor pendukung dan penghambat dalam pelaksanaan layanan bimbingan \\
& kelompok dengan metode sosiodrama dalam meningkatkan komunikasi siswa pada siswa \\
& kelas VII MTs. An-Najah I karduluk. \\
& Metode penelitian yang digunakan adalah PTBK. Penelitian ini dilaksanakan di MTs. \\
& An-Najah I karduluk dengan subyek penelitian seluruh siswa kelas VII sebanyak 20 \\
& siswa. Penelitian ini dilaksanakan dengan 2 siklus dan setiap siklus memiliki 3 kali \\
& pertemuan. Teknik pengumpulan data yang digunakan adalah observasi, wawancara dan \\
& dokumentasi. Teknik analisis data pada penelitian ini adalah statistik deskriptif. \\
& Hasil penelitian ini menunjukkan bahwa teknik sosiodrama dapat meningkatkan \\
& kemampuan komunikasi lisan siswa kelas VII MTs An-Najah I. Peningkatan kemampuan \\
\hline
\end{tabular}

[Type here] 
komunikasi lisan sebelum tindakan sebesar 46.6. Pada siklus I diperoleh skor rata-rata sebesar 76.09, terjadi peningkatan skor sebesar 29.49. Pada Siklus II diperoleh skor ratarata 88.40 , terjadi peningkatan skor sebesar 12.31 dari siklus I. Sehingga diperoleh peningkatan skor sebesar 41.8 dari pra tindakan hingga siklus II. Faktor pendukung adalah suasana kelas yang kondusif, sedangkan faktor penghambatnya yaitu kurangnya alat-alat pendukung dalam pelaksanaan sosio drama.

(C)Edu Consilium: Jurnal BK Pendidikan Islam

Bimbingan dan Konseling Pendidikan Islam

Institut Agama Islam Negeri Madura, Indonesia

\section{PENDAHULUAN}

Bimbingan dan konseling merupakan bidang layanan yang berkembang secara dinamis. Ilmu pengetahuan mengenai bimbingan dan konseling juga berkembang dari tahun ke tahun dan dekade ke dekade. Perubahan dalam sebuah bidang kajian tentunya harus disikapi secara responsif oleh profesi di bidang tersebut, sebagai bentuk kekinian (up to date) layanan profesional yang diberikan.

Perkembangan bimbingan dan konseling di Indonesia tidak terlepas dari perkembangan di negara asalnya Amerika Serikat. Bermula dari banyaknya pakar pendidikan yang telah menamatkan studinya di negeri Paman Sam itu dan kembali ke Indonesia dengan membawa konsep-konsep bimbingan dan konseling yang baru. Hal itu terjadi sekitar tahun 60-an. Saat itu para pakar pendidikan telah menggunakan dasar-dasar pemikiran yang diambil dari pustaka Amerika Serikat. Khusus mengenai pandangan terhadap anak didik yaitu bahwa anak didik mempunyai potensi untuk berkembang karena itu pendidikan harus memberikan situasi kondusif bagi perkembangan potensi tersebut.

Bimbingan dan konseling dapat diartikan sebagai seperangkat program pelayanan bantuan yang dilakukan melalui kegiatan perorangan dan kelompok untuk membantu peserta didik melaksanakan kehidupan sehari-hari secara mandiri dan berkembang secara optimal, serta membantu peserta didik mengatasi masalah yang dialaminya.

Layanan yang dapat diberikan oleh bimbingan dan konseling kepada anak didik dapat dilakukan secara individual maupun kelompok. Layanan bimbingan dan konseling secara individual diberikan kepada aanak didik yang membutuhkan konseling secara khusus. Hal ini perlu dilakukan karena ada anak didik mempunyai cara dan model belajar yang berbeda satu sama lain. Demikian pula apabila ada kekhususan masalah yang sedang dihadapi oleh anak didik sehingga membutuhkan layanan bimbingan dan konseling secara khusus atau individual pula.

Layanan bimbingan dan konseling dapat pula diberikan secara kelompok pada sejumlah siswa dengan hambatan atau problem serupa. Misalnya, kepada sekelompok anak 
didik yang akan menghadapi sebuah perlombaan, terlibat perkelahian, memperoleh nilai di bawah rata-rata, atau pada anak didik yang berprestasi dalam bakat dan minat tertentu.

Layanan bimbingan kelompok merupakan suatu cara memberikan bantuan (bimbingan) kepada individu (siswa) melalui kegiatan kelompok. Dalam layanan bimbingan kelompok, aktifitas dan dinamika kelompok harus diwujudkan untuk membahas berbagai hal yang berguna bagi pengembangan atau pemecahan masalah individu (siswa) yang menjadi peserta layanan. Dalam layanan bimbingan kelompok dibahas topik-topik umum yang menjadi kepedulian bersama anggota kelompok. Masalah yang menjadi topik pembicaraan dalam layanan bimbingan kelompok dibahas melalui suasana dinamika kelompok secara intens dan konstruktif, diikuti oleh semua anggota kelompok dibawah bimbingan pemimpin kelompok (pembimbing atau konselor).

Layanan bimbingan kelompok membahas materi atau topik-topik umum baik topik tugas maupun topik bebas. Yang dimaksudkan topik tugas adalah pokok bahasan yang diberikan oleh pembimbing (pimpinan kelompok) kepada kelompok untuk didiskusikan bersama. Sedangkan topik bebas adalah suatu pokok bahasan yang dikemukakan secara bebas oleh anggota kelompok secara bergiliran, anggota kelompok mengemukakan topik secara bebas, selanjutnya dipilih mana yang akan dibahas terlebih dahulu dan seterusnya.

Perkembangan anak meliputi beberapa aspek perkembangan. Salah satu aspek yang penting dalam perkembangan anak adalah perkembangan bahasa dimana perkembangan bahasa ini berkaitan dengan perkembangan lainnya. Dalam hidup bermasyarakat orang yang tidak pernah berkomunikasi dengan orang lain niscaya akan terisolasi dari lingkungannya. Pengaruh keterisolasian ini dikhawatirkan dapat menimbulkan permasalahan yang kompleks, seperti tidak berkembangnya pengetahuan dan informasi baru yang bersumber dari masyarakat, serta apabila memiliki masalah sangat besar kemungkinan untuk mengalami kesulitan dalam proses penyelesaiannya.

Siswa sebagai bagian dari masyarakat dituntut dapat berkomunikasi dengan orang lain di lingkungan di mana siswa berinteraksi. Lingkungan yang dimaksud adalah sekolah, karena hampir sebagian waktu siswa banyak digunakan untuk berinteraksi di sekolah. Di lingkungan sekolah siswa akan senantiasa berkomunikasi dengan teman sebayanya, dengan gurugurunya, dan dengan tenaga kependidikan yang senantiasa mereka temui di lingkungan sekolah. Tugas pokok siswa di sekolah adalah belajar, dengan belajar siswa akan memperoleh perubahan yang positif dan dapat berkembang secara optimal serta siap melaksanakan peranannya di masa yang akan datang. 
Istilah komunikasi atau dalam Bahasa Inggris communication berasal dari kata Latin communicatio, dan dari kata communis yang berarti sama-makna. Jadi apabila dua orang terlibat dalam komunikasi misalnya dalam bentuk percakapan, maka komunikasi akan terjadi atau berlangsung selama ada kesamaan makna mengenai apa yang dipercakapkan, atau bisa dikatakan komunikasi adalah proses interaksi kegiatan manusia yang terdiri atas dua orang atau lebih yang saling memengaruhi dan bertukar informasi.

Komunikasi adalah penyampaian pengertian antar individu. Ia menyatakan pula bahwa semua manusia dilandasi kapasitas untuk menyampaikan maksud, hasrat, perasaan, pengetahuan dan pengalaman dari orang yang satu kepada orang yang lain. Pada intinya komunikasi adalah pusat minat dan situasi perilaku di mana suatu sumber menyampaikan pesan kepada orang penerima dengan berupaya memengaruhi perilaku penerima tersebut.

Secara singkat, dapat disimpulkan bahwa komunikasi adalah salah satu aktivitas yaang sangat fundamental dalam kehidupan manusia. Kebutuhan manusia untuk berhubungan dengan sesamanya keterampilan berkomunikasi adalah proses interaksi kegiatan manusia yang terdiri atas dua orang atau lebih yang saling memengaruhi dan bertukar informasi, pengetahuan, pikiran agar dapat menggugah partisipasi satu sama lain, sehingga informasi yang diberitahukan tersebut menjadi milik bersama. Agar mampu memulai, mengembangkan dan memelihara komunikasi yang akrab, hangat dan produktif dengan orang lain, siswa perlu memiliki sejumlah keterampilan dasar berkomunikasi atau ciri-ciri dalam berkomunikasi.

. Berdasarkan hasil observasi MTs Annajah 1 Karduluk, terlihat bahwa keterampilan berkomunikasi lisan di sekolah tersebut kurang begitu diperhatikan. Penekanan pembelajaran berbahasa umumnya masih terletak pada keterampilan menyimak, membaca, dan menulis. Keterampilan berkomunikasi lisan lebih dikesampingkan sehingga tidak jarang terdapat siswa yang tidak dapat menyampikan pesan atau informasi dalam bahasa lisan dengan baik. Hal ini menunjukkan juga bahwa masih banyak siswa yang masih kurang mampu mengekspresikan diri lewat kegiatan berkomunikasi lisan atau dengan kata lain keterampilan berkomunikasi lisan pada siswa masih rendah. Siswa masih sering kali malu ketika diminta bercerita di depan kelas. Bahkan tidak jarang beberapa siswa berkeringat dingin, berdiri kaku, lupa segalanya jika berdiri di depan kelas untuk bercerita. Kondisi ini dimungkinkan karena rendahnya penguasaan siswa terhadap topik yang dibahas sehingga siswa tidak mampu menyampaikan hal-hal yang ingin diucapkan. Akibatnya arah pembicaraan menjadi kurang jelas sehingga inti dari bahasan tersebut tidak tersampaikan. 
Berdasarkan hasil wawancara dengan guru BK MTs Annajah I Karduluk Pragaan Sumenep yaitu Ibu Mutammimah S.Pd. diidentifikasi beberapa faktor yang melatarbelakangi masalah rendahnya kemampuan berkomunikasi lisan pada siswa yaitu: (1) Pengaruh penggunaan bahasa Indonesia di lingkungan keluarga dan masyarakat. Dalam proses komunikasi sehari-hari, banyak keluarga yang menggunakan bahasa daerah sebagai bahasa percakapan di lingkungan keluarga; (2) Siswa yang kurang berminat dan kurang termotivasi dalam kegiatan berkomunikasi lisan; (3) Sikap siswa merasa takut, malu dan kurang percaya diri ketika harus berkomunikasi lisan di depan kelas; (4) Kurangnya latihan keterampilan berkomunikasi lisan yang diterapkan dalam pembelajaran; dan (5) Proses pembelajaran keterampilan berkomunikasi lisan yang diterapkan guru masih menggunakan metode konvensional.

Teknik sosiodrama dapat digunakan untuk menciptakan suasana pembelajaran inovatif. Sosiodrama merupakan salah satu model pembelajaran yang diarahkan pada upaya pemecahan masalah-masalah yang berkaitan dengan hubungan antarmanusia. Kompetensi yang dikembangkan melalui teknik ini antara lain kompetensi bekerjasama, berkomunikasi, tanggung jawab, toleransi, dan menginterpretasikan suatu kejadian, sosiodrama dipergunakan sebagai salah satu teknik untuk memecahkan masalah-masalah sosial dengan melalui kegiatan bermain peran. Di dalam sosiodrama ini sesorang akan memerankan suatu peran tertentu dari situasi masalah sosial. ${ }^{1}$ Sosiodrama adalah permainan peran yang ditunjukkan untuk memecahkan masalah sosial yang timbul dalam hubungan antar manusia. Dari kedua pendapat tersebut dapat disimpulkan bahwa sosiodrama adalah teknik bermain peran dalam rangka untuk memecahkan masalah sosial yang timbul dalam hubungan interpersonal (rasa cemburu, dilema, dan lain sebagainya) yang dilakukan dalam kelompok.

Teknik sosiodrama merupakan salah satu metode pembelajaran dimana peserta didik melakukan suatu kegiatan memainkan peran tokoh lain dengan penuh penghayatan dan kreativitas berdasatkan peran suatu kasus yang sedang dibahas sebagai materi pembelajaran. Melalui penerapan teknik ini diharapkan siswa mampu memfokuskan pikiran, kemampuan, dan pengetahuan yang mereka miliki ke dalam perannya sehingga siswa akan lebih mudah mengorganisasikan ide-ide dan pikiran dalam bahasa lisan. Selain itu, dengan penerapan teknik sosiodrama ini diharapkan siswa mampu memerankan karakter tokoh masyarakat sosial yang diperankannya.

${ }_{1}^{1}$ Roestiyah,StrategiBelajarMengajar (Jakarta: RinekaCipta, 2008), 80. 
Berdasarkan hal tersebut, penelitian ini ingin mengetahui: Pertama, bagaimana penerapan layanan bimbingan kelompok dengan metode sosiodrama dalam meningkatkan komunikasi lisan pada siswa kelas VII MTs. An-najah I Karduluk, Kedua, apa saja faktor pendukung dan penghambat dalam pelaksanaan layanan bimbingan kelompok dengan metode sosiodrama dalam meningkatkan komunikasi siswa pada siswa kelas VII MTs. An-Najah I karduluk.

\section{METODE}

Jenis penelitian ini adalah penelitian tindakan bimbingan dan konseling, penelitian tindakan merupakan penerapan berbagai fakta yang ditemukan untuk memecahkan masalah dalam situas sosial untuk meningkatkan kualitas tindakan yang dilakukan dengan melibatkan kolaborasi dan kerja sama para peneliti dan praktisi.

Kemmis dan Mc.Taggart mengatakan "Penelitian tindakan pada hakikatnya berupa perangkat-perangkat atau untaian-untaian dengan satu perangkat terdiri dari empat komponen, yaitu perencanaan, tindakan, pengamatan dan refleksi. Keempat komponen yang berupa untaian tersebut dipandang sebagai satu siklus. Oleh sebab itu, pengertian siklus pada kesempatan ini ialah suatu putaran kegiatan yang terdiri dari perencanaan, tindakan, pengamatan dan refleksi”.

Penelitian tindakan bimbingan konseling (PTBK) memberikan pembelajaran/ layanan untuk memecahkan masalah dan memperbaiki situasi dengan menerapkan suatu tindakan nyata yaitu diberikannya layanan bimbingan kelompok dalam meningkatkan komunikasi lisan dengan menggunakan metode sosiodrama pada siswa kelas VII MTs An-najah 1 Karduluk Pragaan Sumenep.

Adapun tahap-tahap penelitian tindakan dan bimbingan dan konseling Menurut Kemmis dan Mc Taggart, penelitian tindakan pada hakikatnya berupa rangkaian kegiatan yang terdiri dari empat langkah, yaitu perencanaan, tindakan, pengamatan, dan refleksi. Keempat langkah tersebut dipandang sebagai satu siklus penelitian tindakan. Dengan demikian pengertian siklus pada penelitian tindakan adalah suatu putaran kegiatan yang terdiri dari perencanaan, tindakan, pengamatan, dan refleksi.

\section{HASIL}

1. Pelaksanaan Layanan Bimbingan Kelompok dalam Meningkatkan Komunikasi Lisan Dengan Menggunakan Metode Sosiodrama Pada Siswa MTs An-Najah 1 Karduluk Pragaan Sumenep 
Melalui sosiodrama, siswa mampu memahami aspek-aspek dalam komunikasi lisan, mempraktekan tokoh-tokoh dalam sosiodrama sehingga meningkatkan kemampuan berkomunikasi lisan siswa. Pada siklus I pertemuan pertama, siswa dibagi menjadi tiga kelompok kemudian dilaksanakan sosiodrama dengan judul "Legenda Batu Belah Batu Betangkup", "Legenda Batu Menangis", dan "Karena Sahabat". Siklus I pertemuan kedua siswa masih bersama kelompok yang sama namun antar kelompok saling bertukar judul untuk diperankan. Begitupun pada pertemuan ketiga, sehingga setiap kelompok pernah memerankan semua judul sosiodrama.

Pelaksanaan tindakan pada siklus I belum berjalan dengan lancar karena masih ada beberapa kendala, pada pertemuan pertama jumlah rata-rata pada penilaian tersebut 57.05 adapun kendala tersebut adalah siswa masih merasa takut, malu, dan kurang percaya diri untuk memerankan sosiodrama. Siswa belum terbiasa untuk berkomunikasi dengan menggunakan bahasa Indonesia dengan baik. Selain itu, kerjasama antara anggota kelompok belum terbentuk, dan belum maksimalnya kesadaran siswa untuk menghafal naskah sosiodrama. Akibatnya pencapaian nilai yang diharapkan belum optimal, dengan hal itu sesuai dengan beberapa faktor yang bisa memengaruhi komunikasi lisan dalam segi kedwibahasaannya dimana Peguasaan dua bahasa oleh orang tua yang berbeda budaya akan menyebabkan anak mengalami kesulitan dalam pengucapan kata dan penguasaan kosa kata.

Maka di pertemuan kedua peneliti kembali memberikan motivasi kepada siswa supaya melakukan sosiodrama menjadi lebih baik dan memberi dukungan kepada siswa supaya lebih bersemangat lagi dalam hal memperbaiki komunikasi lisannya, dan pada pertemuan kedua tersebut ada peningkatan meskipun tidak terlalu signifikan yaitu 65.95 yang artinya sebanyak 15 siswa mengalami perubahan dalam aspek kebahasaannya, ketepatan pengucapan dan pendengar memahami maksud dari siswa yang memerankan sosiodrama, meskipun masih ada sebagian siswa yang masih ragu pada saat tampil di depan umum. semua itu terjadi juga pada pertemuan ke tiga pada siklus satu, nilai rata-rata dari pertemuan tersebut naik menjadi 73.45 .

Berbekal pengamatan dan refleksi yang dilakukan, guru dan peneliti mengadakan perbaikan-perbaikan dan melanjutkan pada siklus II. Perbaikan tindakan pada siklus II antara lain pembagian naskah dilakukan beberapa hari sebelum dilaksanakannya kegiatan penelitian, menciptakan suasana kondusif selama penelitian berlangsung, guru memberikan penguatan positif dan motivasi berupa reward kepada siswa untuk berani tampil dengan percaya diri dan 
memberikan penampilan yang baik, serta pemberian informasi terhadap bobot nilai yang dimiliki oleh setiap aspek komunikasi lisan.

Pelaksanaan tindakan pada siklus II dapat berjalan dengan lebih baik dibandingkan pada pelaksanaan tindakan siklus I. Pada siklus II ini dilaksanakan sosiodrama dengan judul "Raksasa", "Mukena Bunda", dan "Karma Seorang Sahabat". Pertemuan kedua dan ketiga pada siklus II ini sama seperti pertemuan kedua dan ketiga pada siklus I, yaitu masing-masing kelompok bertukar judul cerita untuk diperankan. Pelaksanaan penelitian pada siklus II ini sebagian siswa sudah lebih percaya diri untuk memerankan sosiodrama dan mampu berkomunikasi lisan dengan lancar. Hal tersebut ditunjukkan saat siswa bermain sosiodrama, kenyaringan suara siswa menjadi lebih lantang, intonasi lebih jelas dan siswa lebih luwes untuk tampil memerankan sosiorama.

Hasil observasi telah menunjukkan adanya peningkatan kemampuan komunikasi lisan yang ditunjukkan dengan keberanian siswa dalam berkomunikasi lisan di depan umum, mengekspresikan apa yang disampaikan, bersikap tenang ketika berkomunikasi lisan, pandangan yang diarahkan kepada lawan bicara, suara yang nyaring, jelas pengucapan artikulasi dan kelancaran dalam mengucapkan kata-kata ketika berkomunikasi lisan.

Hasil wawancara juga menunjukkan bahwa siswa mengaku lebih bersemangat dan lebih memahami materi mengenai kemampuan komunikasi lisan dibanding dengan suasana belajar klasikal. Siswa merasa lebih memahami cara berkomunikasi lisan dengan baik dan pentingnya bagi kehidupan sehari-hari. Hasil wawancara dengan guru juga terlihat adanya peningkatan kemampuan komunikasi lisan siswa yang signifikan dari sebelum dilakukannya tindakan hingga setelah dilakukannya tindakan pada siklus II. Data yang ada menggambarkan peningkatan kemampuan komunikasi lisan siswa mencapai ketuntasan yang ditentukan, sehingga penelitian pun dilakukan hanya sampai siklus II.

Pembelajaran dengan menggunakan teknik sosiodrama dari kedua siklus ini dapat meningkatkan kemampuan komunikasi lisan siswa, dari kondisi skor awal 46.6 meningkat menjadi 76.09 pada siklus I. Kemudian pada silus II meningkat menjadi 88.40. Hasil penelitian ini telah sesuai dengan tujuan penelitian yaitu pelaksanaan layanan bimbingan kelompok dalam meningkatkan komunikasi lisan dengan menggunakan metode sosiodrama pada siswa kelas VII MTs An-Najah 1 Karduluk Pragaan Sumenep. 


\section{Faktor Pendukung dan Penghambat dalam Pelaksanaan Layanan Bimbingan}

Kelompok Dalam Meningkatkan Komunikasi Lisan Dengan Menggunakan Metode Sosiodrama Pada Siswa Kelas VII MTs. An-Najah 1 Karduluk Pragaan Sumenep

Pada sebuah pelaksanaan layanan yang menerapkan strategi, model, metode atau teknik tertentu pasti dalam pelaksanaannya terdapat faktor pendukung dan penghambat. Demikian juga yang terjadi pada peneliti saat melaksanakan pemberian layanan bimbingan kelompok dalam meningkatkan komunikasi lisan dengan menggunakan metode sosiodrama pada siswa kelas VII MTs An-Najah 1 karduluk pragaan sumenep.

Mengenai faktor penghambat dalam penerapan layanan bimbingan kelompok dengan metode sosiodrama yaitu komunikasi siswa yang berbeda-beda, dapat dilihat dalam proses pra tindakan siswa di ajak melajutkan cerita ada yang masih malu-malu dan kaku dalam mengucapkan dan berekspresi dan siswa belum pernah terbiasa dengan metode sosiodrama sehingga ada siswa yang masih kaku dalam melaksanakan sosiodrama.

Selain itu faktor pendukung dan penghambat dalam penerapan layanan bimbingan kelompok dengan metode sosiodrama yaitu terkait dengan kelebihan dan kekurangan dari metode sosiodrama itu sendiri, yaitu kelebihan sebagai faktor pendukung dan kelemahan sebagai faktor penghambat.

\section{PEMBAHASAN}

Hasil observasi dengan daftar penilaian pada pra tindakan diperoleh hasil skor ratarata 46.6. Pada siklus I diperoleh skor rata-rata sebesar 76.09, terjadi peningkatan skor sebesar 29.49. Pada Siklus II diperoleh skor rata-rata 88.40, terjadi peningkatan skor sebesar 12.31 dari siklus I. Sehingga dapat diperoleh peningkatan skor sebesar 41.8 dari pra tindakan hingga siklus II. Hal tersebut menunjukkan bahwa peningkatan kemampuan komunikasi lisan selalu meningkat pada setiap siklus.

Hasil wawancara menunjukkan bahwa siswa memiliki keberanian untuk berkomunikasi lisan di depan umum setelah melakukan sosiodrama. Siswa juga lebih mengenal banyak kosa kata. Selama kegiatan berlangsung siswa mengaku lebih percaya diri untuk berkomunikasi lisan yang sebelumnya merasa takut, kaku dan malu untuk berkomunkasi lisan dengan orang lain. Siswa mengaku lebih memahami cara berkomuikasi lisan dengan baik setelah mempraktekkan langsung dengan sosiodrama. Peneliti berhasil melaksanakan penelitian sesuai dengan tujuan penelitian, yaitu pelaksanaan layanan 
bimbingan kelompok dalam meningkatkan komunikasi lisan dengan menggunakan metode sosiodrama pada siswa kelas VII MTs An-Najah I karduluk pragaan sumenep.

Yusuf (2004: 97) mengemukakan bahwa pada dasarnya layanan bimbingan dan konseling merupakan proses pemaknaan diri dalam kebermaknaan sosial, atau proses pengembangan pribadi yang bercirikan kesalihan individual (ritual) dan kesalihan sosial. Berdasarkan makna di atas, maka layanan bimbingan dan konseling ditujukan untuk membantu individu agar: (1) Memiliki kesadaran akan hakikat dirinya sebagai makhluk atau hamba Allah; (2) Memiliki kesadaran akan fungsi hidupnya di dunia sebagai khalifah Allah; (3) Memahami dan menerima keadaan dirinya sendiri (kelebihan dan kekurangannya) secara sehat; (4) Memiliki kebiasaan yang sehat dalam cara makan, tidur dan menggunakan waktu luang; (5) menciptakan iklim kehidupan keluarga yang fungsional; (6) mengamalkan ajaran agama (beribadah) sebaik-baiknya, baik yang bersifat hablumminallah maupun hablumminannas; (7) Memiliki sikap dan kebiasaan belajar atau bekerja yang positif; (8) memahami masalah dan menghadapinya secara wajar, tabah atau sabar; (9) Memahami faktor-faktor yang menyebabkan timbulnya masalah atau stress; (10) mampu merubah persepsi atau minat; (11) tidak menyesali peritiwa (musibah) yang telah terjadi, karena seburuk apapun musibah itu pasti ada hikmahnya dan; (12) tidak mendramatisir keadaan, tidak emosional dalam menafsirkan peristiwa yang menimpa, berusaha meredamnya dengan instropeksi diri.

Kelebihan dari teknik sosiodrama yang peneliti lihat saat menerapkan layanan bimbingan kelompok dengan metode sosiodrama ini yaitu siswa dapat memfokuskan fikiran, kemampuan dan pengetahuan yang mereka miliki kedalam perannya sehingga siswa lebih mudah mengorganisasikan ide-ide dan pikiran dalam bahasa lisan, dan tentu saja dapat menjadi pengalaman yang menarik karena siswa belum pernah terbiasa dengan menggunakan metode sosiodrama dalam pelajaran bahasa Indonesia. Sedangkan kelemahannya yang peneliti temui yait kurangnya waktu atau durasi dalam bersisiodrama, ramainya siswa yang menonton pada saat kelompok lain maju untuk memerankan drama juga dengan kurangnya alat-alat pendukung dalam berjalannya drama yang dimainkan dan ruangan yang kurang luas pada saat drama berlangsung hal ini dapat terjadi keramaian pada siswa lain dan siswa yang memerankan tokoh tersebut kurang leluasa dalam berperan. 


\section{SIMPULAN}

Berdasarkan hasil penelitian dan pembahasan, diperoleh kesimpulan bahwa teknik sosiodrama dapat meningkatkan kemampuan komunikasi lisan pada siswa kelas VII MTs AnNajah I karduluk pragaan sumenep. Tindakan pada penelitian ini dilaksanakan melalui dua siklus. Setiap siklus terdiri dari tiga kali pertemuan. Siswa dibagi menjadi tiga kelompok. Pada pertemuan pertama dibagiakan naskah dengan tiga judul sosiodrama, pertemuan kedua setiap kelompok bertukar judul sosiodrama, pertemuan ketiga setiap kelompok juga saling bertukar judul sosiodrama. Sehingga ketiga kelompok tersebut memerankan tiga judul sosiodrama pada setiap siklus.

Faktor pendukung dari pelaksanaan Layanan bimbingan kelompok dalam meningkatkan komunikasi lisan dengan menggunakan metode sosiodrama pada siswa kelas VII MTs An-Najah I karduluk pragaan sumenep yaitu suasana kelas yang kondusif, siswa antusias dan bersemangat. Sedangkan faktor penghambatnya yaitu kurangnya alat-alat pendukung dalam berjalannya drama yang dimainkan dan ruangan yang kurang luas pada saat drama berlangsung, namun itu tidak menjadi penghambat bagi siswa yang lain.

\section{DAFTAR RUJUKAN}

Ahmadi, Abu dan Supriyono, Widodo. 2004. Psikologi Belajar (Edisi Revisi). Jakarta: Rineka Cipta.

Arif, Saiful. 2010. Pembentukan Keterampilan Mengajar. Pamekasan: STAIN Pamekasan Press.

Arikunto. 2013. Suharsimi. Prosedur Penelitian Suatu Pendekatan Praktik. Jakarta: Rineka Cipta.

Buna'i. 2006. Buku Ajar Metodologi Penelitian Pendidikan, Pamekasan: STAIN Pamekasan Press.

Daryanto. 2015. Bimbingan dan Konseling Panduan Guru BK dan Guru Umum. Yogyakarta: Gava Media.

Departemen Kebudayaan dan Pendidikan Direktorat Jendral Pendidikan Tinggi, 1996.

Djamarah, Syaiful Bahri. 2006. Strategi Belajar Mengajar. Jakarta: Rineka Cipta.

Emsir. 2014. Metodologi Penelitian Kualitatif Analisis Data. Jakarta: Rajawali Pres.

Hasyim, Farid. 2107. Bimbingan \& Konseling Religius. Yogyakarta: AR-RUZZ.

Hidayat, Dede Rahmat. 2012. Penelitian Tindakan Dalam Bimbingan Konseling. Jakarta: PT Indeks.

Hidayati, dkk. 2007. Psikologi Perkembangan Anak. Jakarta: Universitas Terbuka.

Hurlock, Elizabeth B. 1987. Perkembangan Anak Jilid 1 dan Jilid 2. Jakarta: Erlangga.

Kasiram, Moh. 2010. Metode Penelitian Kualitatif-Kuantitati. Malang: UIN-Maliki Press.

Lestari, Endang. 2006. Komunikasi yang Efektif. Jakarta: Lembaga Adminitrasi Negara Republik Indonesia.

Meleong. Lexy J. 2002. Metodologi Penelitian Kualitatif. Bandung: PT. Remaja Rosdakarya. Prayitno. 2009. Dasar-Dasar Bimbingan dan Konseling. Jakarta: PT. Rineka Cipta.

Roestiyah. 2008. Strategi Belajar Mengajar. Jakarta: Rineka Cipta. 
Romlah, Tatiek. 2006. Teori dan Praktek Bimbingan Kelompok. Malang: Universitas Negeri Malang.

Sukardi, Dewa Ketut. 2008. Proses Bimbingan dan Konseling di Sekolah. Jakarta: PT. Asdi Mahasatra.

Sukardi. 2003. Metodologi Penelitian Pendidikan. Jakarta: PT Bumi Aksara.

Tohirin. 2015. Bimbingan dan Konseling di Sekolah dan Madrasah (Berbasis Integrasi). Jakarta: PT Rajagrafindo Persada. 